\title{
LIVE CONJOINED TWIN BABIES DELIVERED BY CAESAREAN SECTION: A CASE REPORT
}

\author{
Biswas N1ㄴ, Rout A. J², Mukhopadhyay $\mathrm{G}^{3}$
}

\section{HOW TO CITE THIS ARTICLE:}

Biswas N, Rout A. J, Mukhopadhyay G. "Live Conjoined Twin Babies Delivered by Caesarean Section: A Case Report". Journal of Evolution of Medical and Dental Sciences 2014; Vol. 3, Issue 30, July 28; Page: 8408-8410, DOI: $10.14260 /$ jemds/2014/3061

\begin{abstract}
Conjoined twins, commonly referred to as Siamese twins, are babies connected physically to each other. Depending upon the point of connection, there are different types of conjoined twins. A targeted sonographic examination at midpregnancy can diagnose the entity in most cases. Fetal prognosis depends on the period of gestation at delivery, birth weight, extent of organ sharing by the fetuses and possibility of surgical separation. Viable conjoined twins should be delivered by caesarean section. Here we present a case of thoracopagus twin pregnancy where the fetuses were born alive by $\mathrm{C}$ Section but expired soon after delivery probably because of extreme prematurity and low birth weight.
\end{abstract}

KEYWORDS: Twins, Fetus, Conjoined, Survival, Prognosis.

INTRODUCTION: Conjoined twins are fetuses joined physically at birth. A rare phenomenon, the occurrence is estimated to range from 1 in 50, 000 births to 1 in 200, 000 births, ${ }^{1}$ with a somewhat higher incidence in Southwest Asia and Africa. ${ }^{2}$ Approximately half are stillborn, and a smaller fraction of pairs born alive have abnormalities incompatible with life. The overall survival rate for conjoined twins is approximately $25 \% .^{3}$ The condition is more frequently found among females, with a ratio of $3: 1$.

Two contradicting theories exist to explain the origin of conjoined twins. The older theory is fission, in which the fertilized egg splits partially. The second and more generally accepted theory is fusion, in which a fertilized egg completely separates, but stem cells find like-stem cells on the other twin and fuse the twins together. Conjoined twins share a single common chorion, placenta, and amniotic sac, although these characteristics are not exclusive to conjoined twins as there are some monozygotic but non-conjoined twins that also share these structures in utero.

Conjoined twins are classified according to the most prominent site of conjunction: thorax (thoracopagus); abdomen (omphalopagus); sacrum (pygopagus); pelvis (ischiopagus); skull (cephalopagus), side by side (parapagus) and back (rachipagus). The most common types are: thoracopagus followed by pygopagus and finally by ischiopagus.

Conjoined twins can be diagnosed using standard USG by midpregnancy. The use of high resolution and transvaginal USG makes it possible to diagnose conjoined twins in first trimester. False positive results can occur in first trimester when monoamniotic twins may appear conjoined. If USG diagnoses conjoined twins, a MR imaging may be done to know about the points of connection and organs shared precisely. ${ }^{4}$

Once diagnosed, it is hard time for the parents to decide whether to go for continuation of pregnancy or to terminate it. Consultation with a pediatric surgeon often assists parental decision making. For the purpose of pregnancy termination, vaginal delivery may be allowed because the 
union is most often pliable. Still dystocia is common and uterine or cervical injury may occur. Viable conjoined twins should be delivered by Caesarian section.

In 1987, Dr. Ben Carson made medical history by being the first surgeon in the world to successfully separate siamese twins. Surgical separation of the fetuses may be possible if the essential organs are not shared. Surgery to separate conjoined twins may range from relatively simple to extremely complex, depending on the point of attachment and the internal parts that are shared. Most cases of separation are extremely risky and life-threatening.

In many cases, the surgery results in the death of one or both of the twins, particularly if they are joined at the head. This makes the ethics of surgical separation, where the twins can survive if not separated, contentious.

CASE REPORT: Mrs. X, 33yr aged women at about 8 month gestation, presented to emergency at $11.30 \mathrm{pm}$ with pain abdomen since last few hours. She was a $3^{\text {rd }}$ gravida mother with 2 living children aged 6yr and 3yrs. Both are healthy and were delivered vaginally at hospital. In $1^{\text {st }}$ pregnancy she had irregular antenatal check-up. In her next pregnancy and also in current one, she didn't have any antenatal check-up or any investigations done. She didn't take any medication throughout her antenatal period.

There was no history of any medical or surgical illness throughout this period except fever few days ago which subsided with antipyretic drug only. She had moderate pallor and no other significant finding on general examination. Blood pressure was 130/80 mmHg. Per abdominal examination revealed uterine height more than average raising suspicion of a big baby or twin pregnancy. On per vaginal examination, os was parous with show present. She was kept in observation that night and sent for USG the next morning. Scan showed conjoint living twin of thoraco-omphalopagus type in vertex presentation.

There was no major organ sharing and the babies looked mirror image to each other. The fetus1 was of approx. 30week gestation with $1.3 \mathrm{~kg}$ weight and the fetus 2 was of 32 week gestation and $1.8 \mathrm{~kg}$ weight. Both the babies had ascites and pleural effusion. The mother was in labor with os $4 \mathrm{~cm}$ dilated when she returned from the radiology department. A decision of caesarean section was taken considering the possibility of obstruction. Patient party was counseled about the poor fetal prognosis.

They consented for CS and requested for sterilization operation ignoring the fetal prognosis. Conjoint twin baby delivered by CS was of thoracopagus type. There was no respiratory effort, heart rate was below $60 / \mathrm{min}$. Resuscitation with bag and musk ventilation was done. The babies died after prolonged resuscitation of 15 minutes. Both the babies were girl with combined weight of $3.8 \mathrm{~kg}$. Postoperatively one unit blood was transfused to the mother. Post-operative period was uneventful.

Fig. 1: shows the thoracopagus conjoined twin immediately after caesarean section.

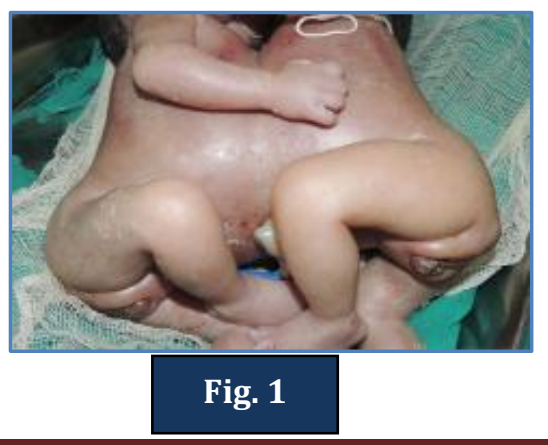


DISCUSSION: Few things are harder than for expectant parents to learn that their unborn child has a life-threatening condition. In the case of conjoined twins, this is doubly difficult not just because there are two babies involved, but also because the children who survive may face tremendous obstacles. Parents in these situations must grapple with very difficult decisions.

Many parents make the difficult decision to end the pregnancy. Prognosis and quality-of-life issues weigh heavily in the decision, as well as the likelihood of successful separation. If the babies share a heart or brain, for example, separation surgery may not be possible.

If the parents choose to continue the pregnancy, mother and babies should be closely monitored throughout the pregnancy. A surgical (C-section) delivery is planned ahead of time, often two to four weeks before the due date.

After the conjoined twins are born, the parents and doctors must decide whether to attempt separation surgery. An emergency separation may be needed if one of the twins dies, develops a lifethreatening condition or threatens the survival of the other twin. More often, however, separation surgery is an elective procedure. If separation surgery isn't possible or the parents decide not to pursue the surgery, comfort care such as nutrition, fluids, human touch and pain relief should be provided.

\section{REFERENCES:}

1. Edmonds LD, Layde PM. Conjoined twins in the United States, 1970-1977. Teratology. 1982; 25: 301-8.

2. Zimmermann AA. Embryological and anatomic considerations of conjoined twins. Birth Defects. $1967 ; 3: 18-27$

3. James L. Stone and James T. Goodrih. The craniopagus malformation: classification and implications for surgical separation. Brain 2006; 129 (5): 1084-1095.

4. Apostolos A, Themistoklis M, Menelaos Z. Prenatal Diagnosis and Management of Conjoined Fetuses. Donald School Journal of Ultrasound in Obstetrics and Gynecology, Jan-Mar 2007; 1 (1): $96-104$.

\section{AUTHORS:}

1. Biswas N.

2. Rout A. J.

3. Mukhopadhyay G

\section{PARTICULARS OF CONTRIBUTORS:}

1. RMO-Clinical Tutor, Department of Obstetrics and Gynaecology, North Bengal Medical College Hospital, Darjeeling, West Bengal.

2. Post Graduate Trainee, Department of Community Medicine, MGM Medical College and LSK Hospital, Kishanganj, Bihar.

3. Associate Professor, Department of Gynaecology and Obstetrics, North Bengal Medical College Hospital, Darjeeling, West Bengal.

\section{NAME ADDRESS EMAIL ID OF THE CORRESPONDING AUTHOR: \\ Dr. Nandita Biswas, \\ \#G-3, Medical Officer Quarter, \\ North Bengal Medical College \\ Hospital Campus, \\ Sushrutanagar, Darjeeling, \\ West Bengal. \\ Email: dr.nandita82@rediffmail.com}

Date of Submission: $13 / 07 / 2014$.

Date of Peer Review: 14/07/2014.

Date of Acceptance: 19/07/2014.

Date of Publishing: 23/07/2014. 